\title{
Characteristics of Secondary Students who have Intentions to Choose a STEM Major in College: Findings from a Three-Year Study
}

\author{
Alpaslan Sahin ${ }^{1 *}$, Hersh C Waxman ${ }^{2}$ \\ ${ }^{1}$ Research Scientist, Director of Research, Harmony Public Schools, 9321 W Sam Houston Pkwy S, Houston, TX 77099, USA \\ 2 Texas A\&M University College Station, USA
}

Received 30 June 2020 - Accepted 6 October 2020

\begin{abstract}
This study was grounded in the social cognitive career theoretical framework (Lent, Brown, \& Hackett, 1994). The purpose of this four-year longitudinal study was to examine the factors that may have contributed to students' motivation to develop STEM interest during secondary school years. The participants in our study were $9^{\text {th }}-11^{\text {th }}$ grade high school students from a large $\mathrm{K}-12$ college preparatory charter school system, Harmony Public Schools (HPS) in Texas. We utilized descriptive statistics and logistic regression analyses to carry out the study. The results revealed that three-year survey takers' STEM major interest seemed to decrease steadily each year. Although there was a significant gender gap between males and females in STEM selection in $9^{\text {th }}$ and $10^{\text {th }}$ grade, this difference was not significant at the end of $11^{\text {th }}$ grade. White and Asian students were significantly more likely to be interested in STEM careers. We also found that students who were most likely to choose a STEM major in college had higher parent and teacher expectations, higher math and science self-efficacy, higher GPA grades, took more AP courses, and participated in STEM clubs.
\end{abstract}

Keywords: social cognitive career theory, STEM interest, in-school, individual, contextual, and motivational factors

\section{INTRODUCTION}

All stakeholders including researchers, policymakers, and members of the business and industry are concerned about the supply-demand issue for qualified professionals in STEM areas. The United States has been experiencing and will continue to experience a shortage of qualified professionals in the STEM workforce (Heaverlo, Cooper, \& Lannan, 2013; Noonan, 2017; Xue \& Larson, 2015). Addressing this shortage is vital for the nation's defense system and for maintaining a cutting edge in today's extremely competitive global market (National Science Board, 2018). There are several facets for remedying the STEM workforce shortage, which includes attracting more people into the STEM workforce and broadening participation in the STEM workforce. The initial and the most challenging step is to recruit more students from diverse backgrounds to pursue college studies in STEM. Once they are in a STEM program in college, retaining them in the STEM pipeline and keeping them engaged in STEM and interested in STEM careers is the priority and another challenging task. There is a myriad of studies conducted on student STEM persistence in college-level experiences (Sass, 2015). However, another imperative task is to encourage students to enter the STEM pipeline before college. Interest in a particular program of study in college and in a particular career after college starts as early as the elementary school, but the most critical step is the high school years because they serve as a gateway into college.

The importance and impacts of pre-college experiences, preparation, and resources on pursuing STEM areas in the future has been brought to attention by several researchers (Crosnoe \& Muller, 2014; Tai, Liu, Maltese, \& Fan, 2006; Wang 2013). Moreover, research indicates that through the end of high school, seniors may lose their motivation (senioritis) to pursue STEM even if they were interested in early years of high school (Icel \& Davis, 2018). Therefore, it is definitely necessary

(c) $\mathbf{2 0 2 0}$ by the authors; licensee Modestum. This article is an open access article distributed under the terms and conditions of the Creative Commons Attribution License (http://creativecommons.org/licenses/by/4.0/). 


\section{Contribution to the literature}

- The results of this study lead to several implications for policymakers, administrators, and educators.

- First, it suggests that school districts and schools can have a positive impact of students' intentions to major in STEM areas.

- A second, critical implication is that there are still STEM aspirational gaps between (a) female and male students, and (b) Hispanic and non-Hispanic students. Although prior research has found that science gaps often begin to occur in elementary schools and are generally stable across secondary school levels (Morgan, Farkas, Hillemeier, \& Macuzuga, 2016), the findings from the present study suggest that there are learning experiences and expectations in high school that may make a difference and reduce the STEM opportunity gap. It is important that schools try to address the serious gaps that already exist in high school in elementary and middle school so that they are reduced or eliminated by the time students enter high school.

- Third, we have found that specific district and school-based programs influence students' STEM career aspirations. Some programs such as STEM Clubs were found to be positively related to students' STEM career interest, while other programs such as Science fairs were not found to significantly predict STEM aspirations.

to identify the characteristics of pre-college students who might matriculate in STEM majors in college and examine what motivates them to do so. Moreover, beyond the rising demand in the STEM workforce (disproportionate to other job areas) and the financial seductive allure of STEM jobs, students' school experience and numerous other contextual factors contribute to students' contemplation about STEM college degrees and STEM careers in future.

The need for more research in identifying pre-college factors contributing to decisions for future STEM endeavors of students motivated this study. This study investigates the factors during the high school years collectively that contribute to students' motivation and interest to go into the STEM pipeline. Grounded in social-cognitively career theoretical framework (Lent, Brown, \& Hackett, 1994), the present study provides critical lenses and a more comprehensive look into the various factors that may contribute to students' motivation in STEM. We tracked $9^{\text {th }}-11^{\text {th }}$ grade high school students from a large K-12 college preparatory charter school system in Texas. Specifically, we present the findings of the first three years $\left(9^{\text {th }}, 10^{\text {th }}\right.$, and $11^{\text {th }}$ grade) of this 4-year longitudinal study.

\section{THEORETICAL FRAMEWORK}

This study is grounded in social-cognitive career theory (SCCT, Lent et al., 1994), which is an extension and application of social-cognitive theory (Bandura, 1986) to career selection. SCCT builds conceptual connections with other theories of career development (e.g., Gottfredson's Theory of Circumscription and Compromise, Self-concept Theory of Career Development) and embraces constructivist assumptions about individuals' capacity to influence their own development (Lent et al., 2002). SCCT was designed to help understand the career development of individual from a wide range of demographic characteristics including gender, race/ethnicity, socioeconomic status, culture, age, and disability status (Lent et al., 2002). SCCT offers a comprehensiveness, practical, tangible, and empirically testable framework (Leung, 2008) which make it particularly suitable for this study. SCCT has not evolved exclusive of these theories of motivation or other career development theories. It is a product of convergence of theory and complementarity in vocational psychology. SCCT brings together conceptually-related constructs such as self-concept and self-efficacy, thus providing a more comprehensive explanation for outcomes and accounting for the interrelations among seemingly diverse constructs (e.g., self-efficacy, interests). SCCT is particularly helpful in providing explanations of how individuals develop competencies and behavior and how they motivate and regulate their own actions (Bandura, 2006).

SCCT suggests that a person's career decision making is shaped by strong personal beliefs developed and cultivated through a sophisticated interaction between the individual and the environment surrounding the individual. The building blocks of this interaction are three major factors: (a) individual inputs (mostly demographic), (b) environmental factors (contextual influences), and (c) behavioral factors (mostly motivational beliefs) (Yu, Corkin, \& Martin, 2016). According to SCCT, the most important factors influencing career decisions relate to student motivation and include self-efficacy, interest, outcome expectations (Eccles, 2005; Schunk, Meece, \& Pintrich, 2014). These psychological variables are also considered to mediate the connection between other personal and contextual factors and future career choice and decisions (Lent \& Brown, 2006; Yu et al., 2016).

In addition to personal motivation, the SCCT framework recognizes several environmental (contextual) factors (e.g., supports and barriers at school and at home) that mold individuals' career aspirations 


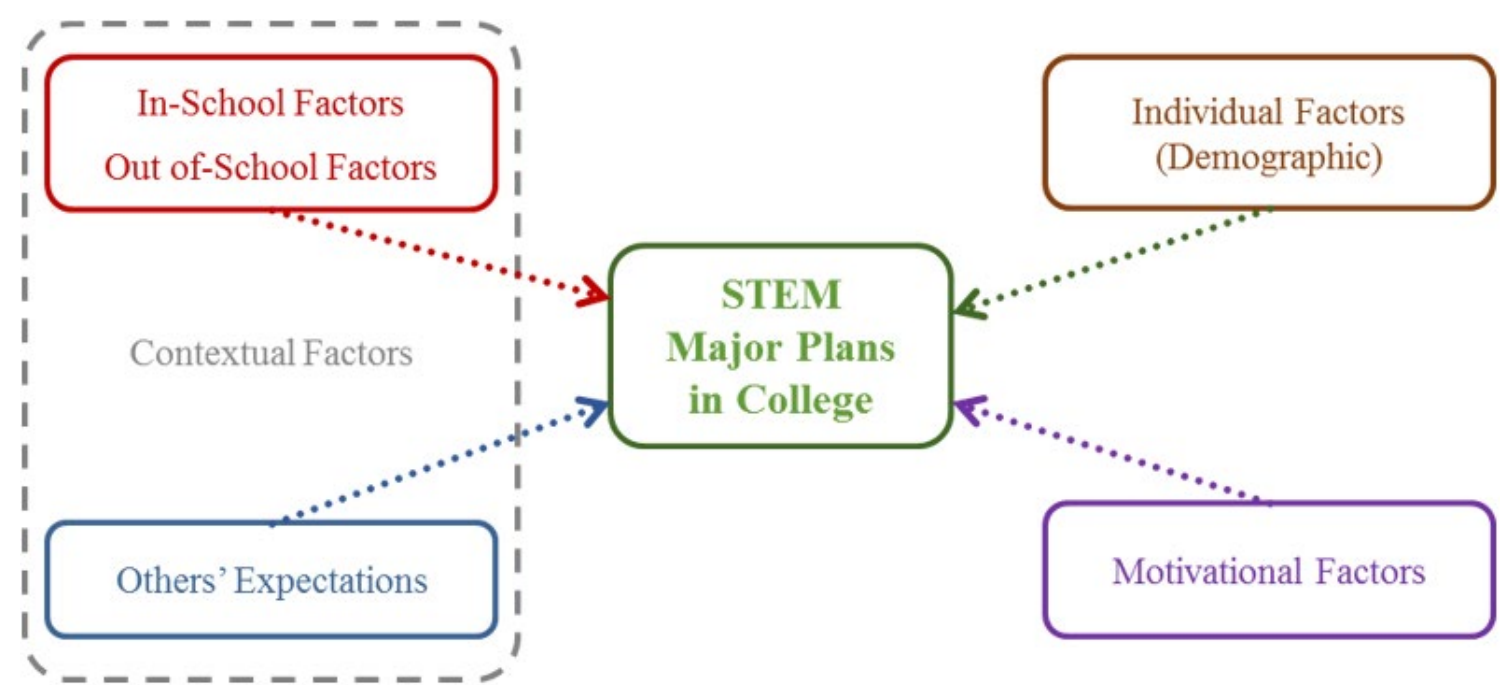

Figure 1. Social Cognitive Career Theoretical framework for this study

and choices (Maltese \& Tai, 2011; Lent \& Brown, 1996; Yu et al., 2016). Specifically, several groups, including parents, peers, and teachers have socializing influences on students' academic and career-related outcomes. The present study integrates SCCT and previous research (e.g., Lee et al., 2015) on factors closely connected with academic choices of high school students and addresses the interconnectedness among their individual, motivational, Pygmalion, and environmental factors and STEM choice (see Figure 1). One of the differences of this study from the previous research is about the variables included. More specifically, based on SCCT and previous research, we included all three groups of variables (individual/demographics, environmental, and behavioral) to develop our instrument in contrast to other studies (e.g., Lee et al., 2015) that included only one or two group of SCCT variables.

\section{A BRIEF REVIEW OF EMPIRICAL EVIDENCE FOR FACTORS AFFECTING STUDENTS' STEM OUTCOMES WITHIN THE SCCT FRAMEWORK}

This section provides key findings of SCCT-related research on students' STEM persistence. Research on or relevant to SCCT has expanded at an impressive rate in early 2000s and it still is quite popular. For instance, selfefficacy, one of major SCCT-related constructs, has been one of the most prevalent topics of inquiry: many studies examine the relation between self-efficacy and theoryrelevant outcomes including career interests, academic subject of study choices, and achievement indicators. More recent studies have explored additional SCCT variables, including outcome expectations, goals, and contextual factors. The following sections provides a brief review highlighting the important findings related to gender and racial gaps, motivational factors, external expectations, and in- and out-of-school STEM experiences, all of which are critical SCCT-factors as introduced in the theoretical framework of this study above.

\section{Gender and Racial Gaps in STEM Motivation and Persistence}

The driving reason behind the numerous calls and efforts to broaden participation in the STEM workforce is unquestionably the persistent gap among certain subpopulations in their educational attainment in STEM areas and employment in the STEM workforce. Gender and racial gaps in STEM education translate into occupational segregation when entering the labor market and disproportionate gains in the long-term economic well-being of individuals. Despite improvement over the years, there is still a significant difference in the procurement of education and employment in the STEM fields among different subpopulations (Business Europe, 2011; National Science Foundation, 2017). Women occupy almost half of the overall jobs in U.S., but account for less than a quarter jobs related to STEM (Beede 2011; Noonan, 2017). Similar disproportionate representations between the overall workforce and the STEM workforce exists in the case of Black and Hispanic populations (Funk \& Parker, 2018). Multiple studies have tried to examine the reasons for these gender and racial disparities in career decisions (Blickenstaff, 2005; Eccles \& Wang, 2016; Riegle-Crumb, Farkas, \& Muller, 2006; Wang \& Degol, 2017), social class/status, and race/ethnicity (Jackson, Suizzo, \& Harvey, 2017; Mau, Perkins, \& Mau, 2016; Yu et al., 2017). For instance, in a study examining the impact of school and out-of-school, and motivational factors on high school students' intention of choosing a STEM major in college, Sahin, Ekmekci, and Waxman (2017b) found significant gender and racial differences. More specifically, males and Asian students are more likely to choose a STEM major in college than females and nonAsian students, respectively. Overall, all these findings 
show that female and students of color are disproportionately represented in STEM areas.

Even the factors influencing students' STEM persistence shows differences based on students' gender and ethnic minority status (Fouad \& Santana, 2017; Mau \& Li, 2018; Riegle-Crumb et al., 2006; Uitto, 2014). In a STEM motivation study at the college-level measuring SCCT-relevant variables in a gateway introductory science course, Hardin and Longhurst (2016) found that female students had lower STEM self-efficacy, coping self-efficacy, and STEM interest than did the male students. In another longitudinal study of science aspirations and careers of young adolescents (age 10-14), DeWitt et al. (2011) and Archer et al. (2012) found that Asian students demonstrated a highly positive set of attitudes towards science and aspirations in science when compared with students from other ethnic/racial backgrounds. Moreover, these gaps may be amplified by the moderating effect of other factors such as other's expectations. For example, research indicates that associations between the expectations of parents and the learning motivation and achievement of students were stronger for boys than for girls (Taskinen, Dietrich, \& Kracke, 2016). In brief, gender, racial, socioeconomic, and other demographic characteristics of students are significantly influential in their development of STEM interest and career outcomes (Eccles \& Wang, 2016; Sahin, Ekmekci, \& Waxman, 2017a, 2017b; Yu et al., 2017).

\section{Motivational Factors}

The most important factors influencing career decisions are those relating to student motivation (Eccles $\&$ Wigfield, 2002). Motivational variables such as selfefficacy, outcome expectations, and interest also mediate the effect of other personal and contextual factors on future career choice and decisions (Lent \& Brown, 2006; 2013; Yu et al., 2016). In addition, individuals' behavior and actions within a domain are primarily influenced by their self-efficacy, outcome expectancy, utility beliefs, and interest within the same and related domains (Bandura, 1986; Eccles \& Wigfield, 2002; Lent \& Brown, 1996). Empirical research indicates that students with higher self-expectations and self-efficacy in STEM subjects are more likely to persist and be successful in these areas (Andersen \& Ward, 2014; Lee, Min, \& Mamerow, 2015, Mujtaba \& Reiss, 2014; Sahin, Ekmekci, \& Waxman, 2017a, 2017b; Uitto, 2014; Wang, 2013).

Similarly, K-12 students' interest and identity beliefs in science and mathematics play a significant role in career interest in STEM (Dabney et al., 2012; Eccles \& Wigfiled, 2002). Lent et al. (2016) have shown that the determination of the college students to stick with their major by the end their junior year was predicted by their willingness to persist, major satisfaction and self-efficacy during their freshman year. Choice to engage in and developing interest in STEM activities are related to the development of a person's identity - to what extend he or she sees themselves as a STEM person (Eccles \& Wigfield, 2002). Pre-college years are crucial to develop motivation for STEM. Maltese and Tai (2011) have shown that students who focus in STEM during college most likely made that choice in high school and that their choice was mostly influenced by their interest in math and science rather than the courses they took or the grades they obtained. This is especially true for lowincome students (Shumow \& Schimdth, 2013). To conclude, motivational factors are central to develop interest in STEM and can even account for gender and socio-economic differences.

\section{External Expectations}

Having discussed individual and motivational factors above, the last component of the present study's conceptual framework is contextual factors, which are also part of SCCT framework and have impact of students' career expectations and interest. Others' (parent, teacher, or peer) expectations are part of contextual factors since they may serve as supports or 1 barriers during the choice-making process regarding future career paths (Lent \& Brown, 1996; 2006; Mujtaba \& Reiss, 2014; Sahin, Ekmekci, \& Waxman, 2017a). The Pygmalion effect indicates that a student will accomplish more, or show higher performance when it is expected of him or her (Rosental \& Jacobson, 1968; Shells, 2015). Likewise, many children will perform well and be more successful in school and life when external factors like their teachers and parents have high expectation of students and support students' choice-making process regarding future career paths of students (Lent \& Brown, 1996; 2006; Mujtaba \& Reiss, 2014; Sahin, Ekmekci, \& Waxman, 2017b). External expectancy may result in actionable consequences on the individual's behalf (DeWitt et al., 2011; Sahin, Ekmekci, \& Waxman, 2017a; Schunk et al., 2014). In a study of low-income schools about students' academic beliefs, Jackson et al. (2017) found that students who have higher science and mathematics teachers' expectations are more likely to have STEM career goals after controlling their grades and mathematics self-efficacy scores than students who have lower science and mathematics teachers' expectations.

Support and encouragement from parents have also been shown to be a significant factor in students' pursuit of STEM degrees. DeWitt et al. (2011) found that parental outlook towards science and their encouragement of students to engage in science-related activities outside of schools strongly predicts students' desire to pursue science. In addition to parental attitudes towards science, parental support is an important factor that encourages students to pursue STEM degrees (Archer et al., 2012; Garriott, Navarro, \& Flores, 2017; Hardin \& Longhurst, 2016; Hui \& Lent, 2018; Sahin, Ekmekci, \& 
Waxman, 2017a; Thomas \& Strunk, 2017). Although empirical evidence exists about the impact of parent and teacher expectations, more research is needed on the links between parents' and teachers' beliefs and children's motivation for STEM (Gunderson, Ramirez, Levine, \& Beilock, 2012), especially from the SCCT perspective (Garriott at el., 2017).

\section{Formal and Informal STEM Experiences}

The second part of contextual factors focuses on students' experience in STEM, both formal and informal or in- and out-of-school STEM learning. Colleges and universities typically make admission decisions on whether students are ready to enter a STEM program or not by evaluating high school course-taking, grade point average (GPA), and college examination scores (Means, Wang, Young, Peters, \& Lynch, 2016). Advanced science and mathematics coursework have been found to be positively associated with enrollment in STEM majors in college. For example, completion of calculus in high school is a significant indicator of readiness for a college STEM major (Sadler, Sonnert, Hazari, \& Tai, 2012). Evidence also supports that high school STEM coursetaking predicts both individual and gender differences in the likelihood of entering STEM careers than does than mathematics achievement (Eccles \& Wang, 2016). In addition, the impact of STEM learning experiences can be long-term. A high school STEM intervention study uncovered that greater high-school STEM course-taking and American college testing (ACT) scores was associated with increased STEM career interest, the number of college STEM courses, and students' attitudes toward STEM, five years after the intervention (Rozek, Svoboda, Harackiewicz, Hulleman, \& Hyde, 2017). Another study comparing inclusive STEM high schools and other high schools in North Carolina, found that "attending STEM schools raised the likelihood of completing pre-calculus or calculus and chemistry in high school, led to increased involvement in STEM extracurricular and out-of-class activities, and enhanced interest in science careers and aspirations to earn a master's or higher degree" (Means et al., 2016, p. 709). This suggests that the more STEM activities and courses students are exposed to, the more likely they are to persist in STEM.

Although course-taking and achievement factors are known to be closely associated with entering a STEM college major and completion of it, there are other formal and informal STEM activities that research indicates as important. These activities can be considered as part of contextual factors in STEM, since they function as opportunities for students to participate in STEM in their current educational context or environment. These other contextual factors as documented by previous research include opportunities to participate in STEM related projects during high school (e.g., Gottfried, \& Williams, 2013), peer interaction (e.g., Frank et al., 2008), and self- efficacy (e.g., Anderson \& Ward, 2014). Moreover, students' participation in out-of-school STEM activities plays a significant role in career interest in STEM (Dabney et al., 2012).

Schools and local education agencies or centers offer programs for STEM learning and often include sustained, self-organized activities for STEM enthusiasts. There is a large body of evidence suggesting that formal and informal STEM programs can stimulate the science-specific interests of its participants (e.g., Sahin, Gulacar, \& Stuessy, 2014; Sevdalis \& Skoumios, 2014), positively influencing students' academic achievement (e.g., Sahin, 2013), and expanding participants' sense of future STEM career options (e.g., Sahin, Ekmekci, \& Waxman, 2017a). Exposure to informal STEM activities also can have long-term effects. Steenbergen-Hu and Olszewski-Kubilius (2017) followed up with high school students who participated in supplemental enriched or accelerated mathematics and science learning activities several years after high school graduation and found that students' experiences in the supplemental outside-of-school STEM programs helped students fortify their interests in STEM and increased their likelihood of earning a college degree in STEM.

\section{Setting: Harmony Public Schools (HPS)}

The HPS is a non-profit open enrollment K-12 college preparatory school district in Texas. It includes more than 50 schools serving a diverse student population of over 35,000 , where $60 \%$ of students receive free or reduced-price lunch and $70 \%$ are under-represented minorities.

Charter schools are also public schools like regular public schools. The charter schools exercise increased autonomy in return for greater accountability. Charter schools are open to all children, do not require entrance exams, cannot charge tuition, and must participate in state testing and federal accountability programs. The schools draw up their own "charter" which is a set of rules and performance standards that they are held accountable to (Caffee, 2018).

The school district has developed its own STEM approach that incorporates project-based and inquirybased learning called "STEM Students on the Stage (SOS TM)" through the Race to the Top grant funded by the U.S. Department of Education with the goal of not only increasing students' STEM knowledge and interest, but also producing self-motivated and self-regulated learners (Sahin \& Top, 2015). They have incorporated the STEM SOS in 6-12 grade teaching mathematics, science, English Language and Arts, and Social studies. It is an interdisciplinary teaching approach and has three parts of project completion: (1) Level 1 projects are short term projects and those are completed during their class times. Level II and III projects are year-long projects. 
Students complete those projects both at school and home/research facilities. The final product includes a video of their project completion from scratch to submission, website, YouTube channel, and brochure explaining the project. Once they complete, they usually present their projects at their annual school STEM festivals and other STEM expos happening within their states. The Harmony Public Schools also offers variety of STEM clubs from math competitions like MATHCOUNTS and American math competition to fun robotics and sea perch clubs. Summer internships and STEM summer camps are also available for those who are interested in. The school district also has an annual science fair competition.

We purposefully selected HPS schools because of the district and school-wide emphasis on integrating STEM across the curriculum and the large student diversity within the school population. Also, HPS provided us with access to the variables we needed in order to test and utilize SCCT as a framework in this study.

\section{PURPOSE OF THE STUDY}

To address the gap in studying pre-college/high school experiences, preparation, motivation, and resources in pursuing STEM areas, it is important to study factors affecting K-12 grade students' future college and career plans in STEM fields. The present paper is part of a 4-year longitudinal study where we aimed how students' high school experience, math and science efficacy, and parent and teacher expectations, and the interplay between them affect their major choice decision when students' gender, ethnicity, and parent variables are controlled. The research questions are as follows:

1. How do the rates of $9^{\text {th }}, 10^{\text {th }}$, and $11^{\text {th }}$ grade common survey takers' intentions to major in STEMrelated fields in college compare to actual rates of college STEM majoring at the state and national level?

2. What are the impacts of in-school and out of school-related activities on students' intention to pursue a STEM degree for 3-year STEM major persisting students after students' and parents' demographic variables are controlled?

3. What are the impacts of both teacher and parental educational (Pygmalion) expectations on students' intentions to pursue a STEM degree for 3-year STEM major persisting students after students' and parents' demographic variables are controlled?

4. What are the impacts of students' motivational (self- educational, mathematics and science expectations) factors on students' intentions to pursue a STEM degree for 3-year STEM major persisting students after students' and parents' demographic variables are controlled?
5. How do 3-year STEM-aspiring students' environmental, Pygmalion, and motivational factors change across the years?

\section{METHODS}

\section{Participants}

Year 1: A total of 2,157 ninth-grade students (class of 2019) from 20 HPS schools were invited and 1,520 (70\%) participated in the study. The 1520 participants included 725 females (48\%), 242 whites (15.9\%), 238 African Americans (15.7\%), 805 Hispanics (53\%), and 228 Asians $(15 \%)$. The similar data for the state of Texas include 13\% African Americans, 4\% Asians, 54\% Hispanics, 29\% whites, and $48 \%$ females.

Year 2: Out of 1945 10th grade students, 1595 (82\%) of them participated in the study in year 2 . The $159510^{\text {th }}$ grade participants included 804 females (50.4\%), 791 males (49.6\%), 229 whites (12\%), 272 African Americans (17\%), 853 Hispanics (54\%), and 240 Asians (15\%). The similar data for the state of Texas for $10^{\text {th }}$ graders include 13\% African Americans, 4\% Asians, 53\% Hispanics, 30\% whites, and $49 \%$ females.

Year 3: A total of $1,62011^{\text {th }}$ graders 22 high schools invited and 1,228 (76\%) participated. The 1228 participants include 594 females (48\%), 634 males (52\%), 164 whites (13\%), 208 African Americans (17\%), 663 Hispanics (54\%), and 192 Asians (16\%). \%). The similar data for the state of Texas for $11^{\text {th }}$ graders include 13\% African Americans, 5\% Asians, 52\% Hispanics, 31\% whites, and $49 \%$ females.

Persisting students: At the end of the third year, 646 students were common participants in all three years. The participants include 318 females (49\%), 328 males (51\%), 95 Asians (15\%), 94 African American (15\%), 374 Hispanics (58\%), and 83 whites (13). Of these 646 participants, 301(47\%) consistently stated that they are planning to major in STEM-related area in college in all three years. Another consistent group was non-STEM choosers with 94 students who consistently persisted on their non-STEM major selection goal for all three years. The remaining 247 students changed their major selection decision at least once between year 1 and year 3.

\section{Instrument}

We used an online survey consisting of 43 questions to request information about five categories of variables: (a) student demographics, (b) family context, (c) school and out-of-school related activities, and (d) Pygmalion effect variables (parent and teacher expectations), and (e) students' self-expectations about their future education, and mathematics and science efficacy (see Appendix A). The current instrument was adapted from previously developed and validated scales (Lee et al., 2015; Sahin, Ekmekci, \& Waxman, 2017a, 2018, 2019). The same 
Table 1. Percentages Three Year Common Takers' Year 1, 2, and 3 STEM Major Plans by their Demographics (n=646)

\begin{tabular}{|c|c|c|c|c|c|c|c|}
\hline & Male & Female & AA & Asian & Hispanic & White & Overall \\
\hline HPS 9th Graders & $79 \%$ & $72 \%$ & $76 \%$ & $86 \%$ & $73 \%$ & $75 \%$ & $76 \%$ \\
\hline HPS $10^{\text {th }}$ Graders & $74 \%$ & $59 \%$ & $74 \%$ & $81 \%$ & $60 \%$ & $72 \%$ & $67 \%$ \\
\hline HPS $11^{\text {th }}$ Graders & $60 \%$ & $59 \%$ & $60 \%$ & $76 \%$ & $52 \%$ & $74 \%$ & $60 \%$ \\
\hline State Average ${ }^{1}$ & $46 \%$ & $14 \%$ & $25 \%$ & $36 \%$ & $31 \%$ & $33 \%$ & $28 \%$ \\
\hline National Average $^{2}$ & $45 \%$ & $15 \%$ & $25 \%$ & $37 \%$ & $30 \%$ & $33 \%$ & $27 \%$ \\
\hline
\end{tabular}

Note: 'Texas' 2018 STEM \& Innovation Report CardTM, ${ }^{2}$ Texas' 2017 STEM \& Innovation Report Card ${ }^{\mathrm{TM}}$

Table 2. Impacts of School and Out of School-Related Activities on STEM Major Selection for Three-Year Persisting Students

\begin{tabular}{lccc}
\hline & B & Sig. & Exp(B) \\
\hline Gender & .086 & .627 & 1.089 \\
African American & .207 & .421 & 1.230 \\
Asian & $.734^{* *}$ & .009 & 2.084 \\
White_ & $.719^{*}$ & .020 & 2.053 \\
Free Reduced & .172 & .376 & 1.188 \\
Parent College Ed in the US & -.008 & .969 & .992 \\
Count Science Fair Participation & -.006 & .936 & .994 \\
GPA & $.536^{* * *}$ & .000 & 1.708 \\
Count STEM Club & $.360^{* * *}$ & .000 & 1.433 \\
Constant & $-1.783^{* * *}$ & .000 & .168 \\
\hline
\end{tabular}

Note: ${ }^{*} p<.05,{ }^{* *} p<.01,{ }^{* * *} p<.001$

instrument was administered to students each of the three years. One of the parts adapted from Friday Institute for Educational Innovation (2012) was about students' math and science-self efficacy levels. Cronbach's alpha reliability values for math self-efficacy (8 items) and science self-efficacy (9 items) were calculated and found high (.925 and .932 , respectively).

\section{Variables}

We used students' intention of choosing a STEM major (Yes/No) in college as our dependent variable. Students indicated 'Yes' as majoring in STEM-related area or 'No' indicating not STEM majoring area. There were two different questions measuring this (Question 19 and Question 26) (see Appendix A). Q19 was a yes/no question asking whether students were planning to major in a STEM-related area in college. To cross check students' answers, we asked the second question what career they want to work at after graduating from a college (Q26). We used National Science Foundation (2010)'s list of career classification and medicine-related careers for the question 26. Then, we coded students' choices of careers as STEM and non-STEM. Finally, after we compared students' answers to Q19 with their answers to Q26, we created a binary dependent variable as 1 (STEM) and 0 (non-STEM). Our independent variables were all environmental, Pygmalion, individual, and contextual factors.

\section{Analyses}

For the first research question, we provided all three years' common survey takers' descriptive statistics. For questions 2-4, we ran multiple logistic regressions to investigate which set of independent variables predict students' probability of choosing a STEM major. Before we ran multiple logistic regression, we verified the assumptions of absence of multicollinearity, independence of errors, and linear relationship between the independent variables and the log odds (Meyers, Gamst, \& Guarino, 2006). For question 5, we used dependent samples $t$-tests and one-way ANOVAs to compare two and three-year data in terms of the differences in the predictive variables used in previous research questions. We used SPSS 26.0.0.0 version to carry out all the analyses mentioned above.

\section{RESULTS}

\section{Research Question 1}

Overall, descriptive statistics revealed that HPS students had higher rates in STEM career interest in all categories including gender and race/ethnicity throughout each of the three years of the study. There was a steady decrease from $9^{\text {th }}$ to $11^{\text {th }}$-grade in students' interest in choosing a STEM-related major in college (see Table 1). However, HPS students' rates are still substantially higher than the average number of STEM major students in the state of Texas and the Nation. Overall HPS students' STEM selection interest decreased from $76 \%$ to $60 \%$ between year 1 and year $3(16 \%$ decrease).

\section{Research Question 2}

The Hosmer and Lemeshow test of the goodness of fit suggested that the model was a good fit to the data as $p=.418$ (>.05). Logistic regression results (see Table 2) indicated that there was no significant difference in STEM major selection among three-year participating 
Table 3. Impacts of Pygmalion Effect Variables on STEM Major Selection for Three-Year Persisting Students

\begin{tabular}{lccc}
\hline & $\mathrm{B}$ & Sig. & $\mathrm{Exp}(\mathrm{B})$ \\
\hline Gender & .150 & .376 & 1.162 \\
African American & .248 & .299 & 1.281 \\
Asian & $1.003^{* * *}$ & .000 & 2.726 \\
White & $.806^{* *}$ & .006 & 2.239 \\
Free Reduced Lunch & .068 & .710 & 1.070 \\
STEM Teacher Expectation & $.347^{* * *}$ & .000 & 1.415 \\
Parent Expectation & $.313^{*}$ & .019 & 1.367 \\
Constant & $-2.183^{* * *}$ & .000 & .113 \\
\hline
\end{tabular}

Note: ${ }^{*} p<.05,{ }^{* *} p<.01,{ }^{* * *} p<.001$

Table 4. Impacts of Self-Expectation, Math and Science Efficacy Variable on STEM Major Selection for Three-Year Persisting Students

\begin{tabular}{lccc} 
& B & Sig. & Exp(B) \\
\hline Gender & -.147 & .444 & .863 \\
African American & .072 & .798 & 1.074 \\
Asian & $.700^{*}$ & .017 & 2.014 \\
White & $.795^{*}$ & .015 & 2.215 \\
Free Reduced Lunch & .086 & .677 & 1.090 \\
Self-Expectation & .014 & .858 & 1.014 \\
Math Self-Efficacy & $.654^{\star * *}$ & .000 & 1.923 \\
Science Self-Efficacy & $1.243^{* * *}$ & .000 & 3.465 \\
Constant & -5.949 & .000 & .003 \\
\hline
\end{tabular}

students of $11^{\text {th }}$ grade by gender. The same thing is true for students of different socio-economic status. There was no statistical difference in STEM-related area consideration among $11^{\text {th }}$ grade students on whether they are coming from low income families or not. Yet, $11^{\text {th }}$ grade Asian and White students were 2.08 and 2.05 times more likely to contemplate majoring in a STEM field than their Hispanic peers, respectively. Moreover, $11^{\text {th }}$ grade students who had higher number of STEM club participation and higher GPAs were more likely to consider a STEM major in college compared to their counterparts with less number of STEM club participation and lower GPAs respectively (1.4 and 1.7 times).

\section{Research Question 3}

The Hosmer and Lemeshow test revealed that our model was a good fit to the data as $p=.865$ (>.05). For the third research question, the logistic regression analysis revealed that there were no statistical difference male and female students in terms of planning to major in STEM areas in college (see Table 3 ). Asian and White junior students are 2.7 and 2.2 times more likely to consider a STEM college major than Hispanic junior students, respectively. Junior students who have higher STEM teacher and parent expectations are 1.4 times more likely to choose a STEM-related field in college than their counterparts with less STEM teacher and parent expectation.

\section{Research Question 4}

For the fourth research question, the Hosmer and Lemeshow test revealed that our model was a good fit to the data as $p=.993(>.05)$. There was no significant difference between male and female persisting juniors in contemplating to major in a STEM area in college (see Table 4). Similar to the findings in research question 2 and 3, Asian and White junior students again had higher odds of considering a STEM degree in college (odds ratios: 2 and 2.2, respectively). In addition, higher mathematics and science self-efficacy were also significantly associated with higher odds of considering a STEM degree in college (odds ratios: 1.9 and 3.5, respectively).

\section{Research Question 5}

At the end of the third year, there were 646 common participants who completed surveys for all three years. In other words, the same 646 participants participated in year 1, 2, and 3's studies separately each year. Of the 646 participants, 301(47\%) consistently stated that they were planning to major in STEM-related area in college in each of the three years.

To answer the last research question, we paid close attention to the predictive factors and tried to identify how STEM-persisting students' (301) factors changed over the years so that we could find out the pattern that may lead any secondary grade students to major in STEM in college. We had STEM-persisting students' STEM club participation, number of Advanced Placement (AP) course taking, Grand Point Averages (GPA), self-expectation scores, parent and STEM teacher expectation scores, and mathematics and science-self efficacy scores available. We ran paired-samples t-test for the students' STEM club participation because their 
year 1 data was not available. We found that there was a significant change between year 2 and year $3(t(298)=$ 5.254, $p=.001)$.

Second, we examined how STEM-persisting students' number of AP course taking changed over the years. One-way ANOVA analysis revealed that there was a significant change $(F(2,680)=140.018)$ in numbers of total AP course taking between years. It seemed the number increased each year. But the significant difference was between year 2 and year 3(p=.001). We ran another one-way ANOVA analysis for the persisting students' educational self-expectation. It came out that there was no significant change across the years $(F(2,841)=.930, p=.395)$. Paired-samples analysis of year 2 and year 3' GPA scores revealed that there was a significant difference between year 2 and $3(t(293)=$ 3.939, $p=.001$ ). Year 2 GPA average was significantly increased from 2.85 to 3.09 in year 3 .

We ran one-way ANOVA analysis to find out whether there was a significant change among STEM persisting students' parent expectation over the years. We found that although parents' expectation steadily increased across the years, this difference was not significant $(F(2,900)=1.792, p=.167)$. One-way ANOVA analysis revealed that HPS students' STEM teacher expectations significantly changed across years $(F(2$, $899)=3.190, p=.042$ ). Post Hoc analysis showed that STEM teachers' expectations significantly increased from year 2 to year $3(p=.050)$ for STEM persisting students.

The math and science self-efficacy instrument we used for year 2 and year 3 were the same. Therefore, we only compared those two-year scores with each other. We run paired-sample t-test. We found that there was a statistically significant difference between year 2 and year $3(t(300)=-14.294, p=.001)$. HPS students' math selfefficacy significantly increased from year 2 to year 3 . For the students' science self-efficacy, we ran another pairedsample $t$-test analysis. It revealed that there was a significant difference between year 2 and year 3 students' science self-efficacy scores $(t$ (293) $=-5$. 225.p=.001) HPS students' science self-efficacy scores statistically increased from year 2 to year 3 .

\section{DISCUSSION}

In the present longitudinal study, we examined $9^{\text {th }}$, $10^{\text {th }}$, and $11^{\text {th }}$ grade CCS students' perceptions of whether they would choose STEM as their major in college and what factors they perceived may have been related to their interest for choosing STEM as their college major.

Our first research question examined HPS students' intentions to major in STEM-related fields in college and compared them to actual rates of college STEM majors at the state and national level. We found that HPS students' interest to STEM majoring decreased steadily among years. This decrease was sharper between year 1 and year 3. Overall, 3-year persisting survey takers' STEM major interest decreased from $76 \%$ in $9^{\text {th }}$ grade to $60 \%$ in $11^{\text {th }}$ grade although the average rate is still substantially higher than both the state and Nation rates regardless of all subgroups. This finding was similar to Munce and Fraser's (2012) data that indicates that high school seniors are about $10 \%$ less likely than high school freshmen to indicate interest in STEM majors. Of the 646 three-year participating students, female and male students' STEM selection rates for year 3 were 48 and $52 \%$ respectively. The difference was not statistically significant $\left(x^{2}(1,645)=.357, p=.575\right)$ although for years 1 and 2 , these gender differences were statistically significant. This reduction of the gender gap in STEM career choice is one of the most important findings from this study and it suggests that HPS may be implementing STEM-related activities in high school that are narrowing these persistent gender gaps.

Our second research question investigated the impacts of school and out of school-related activities on $11^{\text {th }}$ grade students' intention to pursue a STEM degree. We found that $11^{\text {th }}$ grade students who participated in more STEM clubs were significantly more likely to have interest in a STEM career than students who participated less in STEM clubs. We did not find, however, that students' participation in science fairs was associated with interest in STEM careers. We also found that there were no differences by (a) students' gender, (b) free lunch, and (c) parents' college education in the US. In fact, these findings were consistent for all our logistic regression analyses.

It is important to highlight that parents' college degree, and household income did not impact students' intent to enroll in a STEM major in college. These parent background variables are often used as excuses as to why students' are not interested in STEM fields, but our findings suggest that they may not be influential in impacting students' STEM career aspirations or this particular HPS may be impacting students' interest in STEM in a way that eliminates the negative impact of family background variables. Similarly, the finding that there were no gender differences is also noteworthy. There have been many reports and studies that have argued that women are less interested in STEM careers than men (Beede, 2011; Noonan, 2017), but we found that when you have comprehensive regression models that statistically control for other background variables (e.g., SES, parent education, ethnicity), females have as much interest in STEM careers as men. This positive finding may also be attributed to this HPS's STEM program, which seems to have a positive impact on students' STEM interest, and to reduce the gender, social class, and racial/ethnic disparities in students' STEM interest.

The third research question examined the impacts of both teacher and parental educational expectations on $11^{\text {th }}$ grade students' intentions to pursue a STEM degree. 
We found that students who had higher teacher and parent expectations were about 1.4 times more likely to choose a STEM-related career than students who had lower teacher and parent expectations. These findings are similar to prior research showed that teacher expectations (Heaverlo, 2011; Heaverlo, Cooper, \& Lannan, 2013; Shumow \& Schmidt, 2013) and parent expectations (Archer et al., 2012; Lee, Min, \& Manerow, 2015) strongly increases the likelihood of students persisting in STEM fields. These findings also lend support to the importance of social cognitive theory (SCCT) that focuses on how Pygmalion factors such as parent and teacher expectations are associated with career choice.

Our fourth research question examined $11^{\text {th }}$ grade students' self-expectations, mathematics, and science self-efficacy on their intentions to pursue a STEM degree. We found that students' mathematics and science selfefficacy significantly predicted students' self-interest in STEM careers. In fact, science self-efficacy had the highest odds ratio (3.5) of all the variables that we used to predict students' interest in STEM careers. This is parallel with the previous research. For example, Mau and $\mathrm{Li}$ found that students' math and science selfefficacy were the most important predictors of STEM career interest. Surprisingly, students' self-educational expectations (i.e., educational aspirations) were not found to be significantly related to students' interest in STEM careers. It may be that the measurement of this variable did not yield adequate variance in students' responses.

The fifth research question examined how three-year STEM aspiring students' environmental, Pygmalion, and motivational factors change across the years. In other words, we tried to identify how STEM-persisting students' factors changed over the years so we could find out patterns that may lead any secondary grade students to major in STEM in college. We found no significant differences across the years for students' educational aspirations and parent expectations. We did, however, find significant increases between $10^{\text {th }}$ and $11^{\text {th }}$ grade on students' STEM club participation, AP courses taken, GPA, teachers' expectations, mathematics self-efficacy, and science self-efficacy. In other words, we might say that students who choose or major in STEM-related areas are the ones with more or better of above findings. Indeed, there are research out there supporting some of these findings. For example, Chittum, Jones, Akalin, and Schram (2017) found that participation to afterschool STEM programs increased students' STEM motivation. Similarly, students with higher math and science efficacy scores are more likely to major in STEM fields compared those with low math and science efficacy scores (e.g., Mau \& Li, 2018; Sahin, Ekmekci, \& Waxman, 2017).

\section{Limitations and Future Research}

One limitation of the study relates to the measurement of variables. Although student self-report measures have been in many similar STEM studies (e.g., Gottfried \& Williams, 2013; Lee, Min, \& Mamerow, 2015), there are some concerns about the use of such measures due to the uncertainty of the instrument's construct validity and reliability. Future studies could address this issue by either (a) including more similar items so that construct validity and internal consistency reliabilities could be calculated, or (b) developing a strategy to resurvey a small sample of the same students after a few weeks in order to determine the test-retest reliability of the instrument. There are some concerns about using either approach since they both may result in lowering the response rate of the survey.

Another limitation of this study is that we are measuring students' "intentions" to major in STEM areas rather than students "actually" majoring in STEM fields. We plan to continue this longitudinal study so that we can determine the degree that students' intentions in high school are related to their actual enrollment in STEM fields.

A final limitation of the study is that it was conducted in one large school district that was implementing an integrated STEM curriculum for several years. For future studies, it would be interesting to include other large school districts so that we could possibly compare across districts on the how the three factors of (a) demographics, (b) school and out-of-school factors, and (c) Pygmalion effect variables such as student, teacher, parent expectations and students' mathematics and science efficacy differentially affect students' choosing STEM majors in college.

Additional studies using mixed-methods methodology including qualitative interviews would be useful to examine in more depth "why" high school students are interested in STEM careers and "why" they sometimes change their interest over time. Similarly, it may important to specifically focus on $11^{\text {th }}$ grade female students to understand why they become more interested in STEM careers. Furthermore, more qualitative data about their experiences in school as well as their home environment could be important for further understanding about the SSCT theory. Future research may also want to explore how other social, political, and cultural factors affect students' pursuits of STEM careers. Students' identities as STEM people and students' ideas of ownership of STEM, for example, are other areas that could be further explored since some previous research has found that those factors are critical factors that reduce race and gender gaps in science attitudes (LaForce, Noble, Zuo, \& Ferris, 2018). 


\section{Conclusions}

The results of this study lead to several implications for policymakers, administrators, and educators. First, it suggests that school districts and schools can have a positive impact of students' intentions to major in STEM areas. About $68 \%$ of the $11^{\text {th }}$ grade-HPS students who responded to this survey are contemplating majoring in STEM areas. This is a remarkable finding given that $60 \%$ of the HPS students receive free or reduced price lunch and $70 \%$ are under-represented minorities (Hispanics and blacks). Overall, these findings from our study are especially encouraging because they suggest that schools serving students from disadvantaged circumstances can implement programs and practices that may impact students' future careers in STEM.

A second, critical implication is that there are still STEM aspirational gaps between (a) female and male students, and (b) Hispanic and non-Hispanic students. Although prior research has found that science gaps often begin to occur in elementary schools and are generally stable across secondary school levels (Morgan, Farkas, Hillemeier, \& Macuzuga, 2016), the findings from the present study suggest that there are learning experiences and expectations in high school that may make a difference and reduce the STEM opportunity gap. It is important that schools try to address the serious gaps that already exist in high school in elementary and middle school so that they are reduced or eliminated by the time students enter high school. Targeted intervention programs may need to be developed to specifically reduce these aspirational gaps.

Third, we have found that specific district and schoolbased programs influence students' STEM career aspirations. Some programs such as STEM Clubs were found to be positively related to students' STEM career interest, while other programs such as Science fairs were not found to significantly predict STEM aspirations. Systematic evaluations of these programs may be needed to inform us how and why they may influence students' career aspirations. Other school districts may want to explore implementing some of the beneficial HPS STEM-related activities/programs that HPS develops for all its students.

Finally, the results highlight the importance of parent and teacher expectations for promoting students' career aspirations in STEM fields. It is important to discuss this specific finding with teachers and parents so that they can continue and increase their encouragement to children. In addition, we found that students with higher measures of mathematics and science efficacy were more likely to consider a STEM field for their college major than students with lower measures of mathematics and science efficacy. This lends support to the importance of social cognitive theory (SCCT) that focuses on how aspects of self-efficacy are associated with career choice. Overall, these findings suggest that districts and schools need to continually focus on the affective dimensions of STEM so that all students feel confident that they can be successful in mathematics and science.

\section{REFERENCES}

American College Testing (2016). The condition of STEM 2016. Retrieved from https://www.act.org/ content/dam/act/ unsecured/documents/STEM2 016_52_National.pdf

Archer, L., DeWitt, J., Osborne, J., Dillon, J., Willis, B., \& Wong, B. (2012). Science aspirations, capital, and family habitus: How families shape children's engagement and identification with science. American Educational Research Journal, 49(5), 881908. https:/ / doi.org/10.3102/0002831211433290

Andersen, L., \& Ward, T. J. (2014). Expectancy-value models for the STEM persistence plans of ninthgrade, high-ability Students: A comparison between black, Hispanic, and white students. Science Education, 98(2), 216-242. https:// doi.org/10.1002/sce.21092

ASTRA's 2018 STEM Innovation Vital Signs Series (2018). Texas' 2018 STEM \& innovation report card ${ }^{\mathrm{TM}}$. Retrieved from https://Www.usinno vation.org/state/pdf_cvd/ASTRA-STEM-on-theHill-Texas2018.pdf

ASTRA's 2017 STEM Innovation Vital Signs Series (2017). Texas' 2017 STEM \& innovation report card ${ }^{\mathrm{TM}}$. Received from https://Www.usinno vation.org/state/pdf_cvd/ASTRA-STEM-on-theHill-Texas2017.pdf

Bandura, A. (1986). Social foundations of thought and action: A social cognitive theory. Englewood Cliffs, NJ: Prentice Hall.

Bandura, A. (2006). Going global with social cognitive theory: From prospect to paydirt. In S. I. Donaldson, D. E. Berger, \& K. Pezdek (Eds.), The rise of applied psychology: New frontiers and rewarding careers (pp. 53-70). Mahwah, NJ: Erlbaum.

Beede, D. N., Julian, T. A., Langdon, D., McKittrick, G., Khan, B., \& Doms, M. E. (2011). Women in STEM: A gender gap to innovation. Washington, DC: U.S. Department of Commerce. https://doi.org/ 10.2139 / ssrn.1964782

Blickenstaff, C. J. (2005). Women and science careers: leaky pipeline or gender filter? Gender and Education, 17(4), 369-386. https:/ / doi.org/10.1080/ 09540250500145072

Bryan, R. R., Glynn, S. M., \& Kittleson, J. M. (2011). Motivation, achievement, and advanced placement intent of high school students learning science. Science Education, 95(6), 1049-1065. https://doi.org/10.1002/sce.20462 
BusinessEurope. (2011). Plugging the Skills Gap - The clock is ticking (science, technology and maths). Brussels, Belgium: Author. Retrieved from https://www. businesseurope.eu/sites/buseur/files/media/im ported/2011-00855-E.pdf

Chittum, J. R., Jones, B. D., Akalin, S., \& Schram. (2017). The effects of an afterschool STEM program on students' motivation and engagement. International Journal of STEM Education, 4(11), 1-16. https:/ / doi.org/10.1186/s40594-017-0065-4

Crosnoe, R., \& Muller, C. (2014). Family socioeconomic status, peers, and the path to college. Social Problems, 61(4), 602-624. https://doi.org/10.1525/ sp.2014.12255

Dabney, K. P., Tai, R. H., Almarode, J. T., MillerFriedmann, J. L., Sonnert, G., Sadler, P. M., \& Hazari, Z. (2012). Out-of-school time science activities and their association with career interest in STEM. International Journal of Science Education, Part B, 2(1), 63-79. https://doi.org/10.1080/ 21548455.2011.629455

DeWitt, J., Archer, L., Osborne, J., Dillon, J., Willis, B., \& Wong, B. (2011). High aspirations but low progression: The science aspirations-careers paradox amongst minority ethnic students. International Journal of Science and Mathematics Education, 9(2), 243-271. https://doi.org/10.1007/ s10763-010-9245-0

Eccles, J. S. (2005). Subjective task value and Eccles et al. Model of achievement-related choices. In A. J. Elliot \& C.S. Dweck (Eds.), Handbook of competence and motivation (pp. 105-121). New York: Guilford.

Eccles, J. S., \& Wang, M. T. (2016). What motivates females and males to pursue careers in mathematics and science? International Journal of Behavioral Development, 40(2), 100-106. https:/ / doi.org/10.1177/0165025415616201

Eccles, J. S., \& Wigfield, A. (2002). Motivational beliefs, values, and goals. Annual Review of Psychology, 53(1), 109-132. https://doi.org/10.1146/ annurev.psych.53.100901.135153

Ekmekci, A., Sahin, A., \& Waxman, H. (2019). Factors affecting students' STEM choice and persistence: A synthesis of research and findings from the second year of a longitudinal high school STEM tracking study. In A. Sahin, \& M. Mohr-Schroeder (Eds). Myths and truths: What has years of stem education research in k-12 taught us? Rotterdam, The Netherlands: Brill.

Ferry, T. R., Fouad, N. A., \& Smith, P. L. (2000). The role of family context in a social cognitive model for career-related choice behavior: A math and science perspective. Journal of Vocational Behavior, 57(3), 348-364. https:/ / doi.org/10.1006/jvbe.1999.1743
Fouad, N. A., \& Santana, M. C. (2017). SCCT and underrepresented populations in STEM fields: Moving the needle. Journal of Career Assessment, 25(1), 24-39. https://doi.org/10.1177/106907271 6658324

Frank, K. A., Muller, C., Schiller, K. S., Riegle-Crumb, C., Mueller, A. S., Crosnoe, R., \& Pearson, J. (2008). The social dynamics of mathematics course taking in high school. American Journal of Sociology, 113(6), 1645-1696. https:/ / doi.org/10.1086/587153

Friday Institute for Educational Innovation (2012). Middle and high school STEM-student survey. Raleigh, NC: Author.

Funk, C., \& Parker, K. (2018). Women and men in STEM often at odds over workplace equity. Washington, DC: Pew Research Center. Retrieved from http:/ / www.pewsocialtrends.org

Garriott, P. O., Navarro, R. L., \& Flores, L. Y. (2017). Firstgeneration college students' persistence intentions in engineering majors. Journal of Career Assessment, 25(1), 93-106. https://doi.org/10.1177/106907271 6657533

Gottfried, M. A., \& Williams, D. (2013). STEM club participation and STEM schooling outcomes. Education Policy Analysis Archives, 21(79), 1-27. https:/ / doi.org/10.14507/epaa.v21n79.2013

Gunderson, E. A., Ramirez, G., Levine, S. C., \& Beilock, S. L. (2012). The role of parents and teachers in the development of gender-related math attitudes. Sex Roles, 66(3-4), 153-166. https://doi.org/10.1007/ s11199-011-9996-2

Hardin, E. E., \& Longhurst, M. O. (2016). Understanding the gender gap: Social cognitive changes during an introductory stem course. Journal of Counseling Psychology, 63(2), 233-239. https://doi.org/ $10.1037 /$ cou0000119

Heaverlo, C. (2011). STEM development: A study of 6th12th grade girls' interest and confidence in mathematics and science. Retrieved from http:/ / lib.dr.iastate.edu / cgi/ viewcontent.cgi?article $=1035 \&$ context=etd

Heaverlo, C. A., Cooper, R., \& Lannan, F. S. (2013). STEM development: Predictors for 6th-12th grade girls' interest and confidence in science and math. Journal of Women and Minorities in Science and Engineering, 19(2), 121-142. https://doi.org/10.1615/Jwomen MinorScienEng.2013006464

Hui, K., \& Lent, R. W. (2018). The roles of family, culture, and social cognitive variables in the career interests and goals of Asian American college students. Journal of Counseling Psychology, 65(1), 98-109. https:/ / doi.org/10.1037/cou0000235

Icel, M., \& Davis, M. (2018). STEM focused high school and university partnership: Alternative solution for senioritis issue and creating students' STEM curiosity. Journal of STEM Education, 19(1), 14-22. 
Jackson, K. M., Suizzo, M. A., \& Harvey, K. E. (2017). Connecting teacher perceptions to stem occupational goals in low income adolescents of color. Journal of Women and Minorities in Science and Engineering, 23(1), 73-86. https://doi.org/10.1615/ JWomenMinorScienEng.2017015905

LaForce, M., Noble, E., Zuo, H., \& Ferris, K. (2018). Can inclusive STEM high school strategies reduce race $\mathcal{E}$ gender gaps in science attitudes? Chicago, IL: Outlier Research Evaluation, University of Chicago STEMEd | The University of Chicago.

Lee, S. W., Min, S., \& Mamerow, G. P. (2015). Pygmalion in the classroom and the home: Expectation's role in the pipeline to STEMM. Teachers College Record, 117(9), 1-36.

Lent, R. W., \& Brown, S. D. (1996). Social cognitive approach to career development: An overview. The Career Development Quarterly, 44(4), 310-321. https://doi.org/10.1002/j.21610045.1996.tb00448.x

Lent, R. W., \& Brown, S. D. (2006). On conceptualizing and assessing social cognitive constructs in career research: A measurement guide. Journal of Career Assessment, 14(1), 12-35. https://doi.org/10.1177/ 1069072705281364

Lent, R. W., \& Brown, S. D. (2013). Social cognitive model of career self-management: Toward a unifying view of adaptive career behavior across the life span. Journal of Counseling Psychology, 60(4), 557568. https:/ / doi.org/10.1037/a0033446

Lent, R. W., Brown, S. D., \& Hackett, G. (1994). Toward a unifying social cognitive theory of career and academic interest, choice, and performance. Journal of Vocational Behavior, 45(1), 79-122. https://doi.org/10.1006/jvbe.1994.1027

Lent, R. W., Brown, S. D., \& Hackett, G. (2002). Social cognitive career theory. In D. Brown (Ed.) Career choice and development (4th ed.), (pp. 255-311). San Francisco, CA: John Wiley \& Sons.

Leung, S. (2008). The big five career theories. https:/ / doi.org/10.1007/978-1-4020-6230-8_6

Maltese, A. V., \& Tai, R. H. (2011). Pipeline persistence: Examining the association of educational experiences with earned degrees in STEM among US students. Science Education, 95(5), 877-907. https:// doi.org/10.1002/sce.20441

Mau, W. C. J., \& Li, J. (2018). Factors influencing STEM career aspirations of underrepresented high school students. The Career Development Quarterly, 66(3), 246-258. https:/ / doi.org/10.1002/cdq.12146

Mau, W. C. J., Perkins, V. J., \& Mau, Y. H. (2016). Gender and racial differences in career decision-making dispositions of college students enrolled in STEM majors. Universal Journal of Psychology, 4(6), 254-260. https:/ / doi.org/10.13189/ujp.2016.040602
Means, B., Wang, H., Young, V., Peters, V. L., \& Lynch, S. J. (2016). STEM-focused high schools as a strategy for enhancing readiness for postsecondary STEM programs. Journal of Research in Science Teaching, 53(5), 709-736. https:/ / doi.org/10.1002/tea.21313

Meyers, L. S., Gamst, G., \& Guarino, A. J. (2006). Applied multivariate research: Design and interpretation $\left(3^{\mathrm{rd}}\right.$ ed.). Thousand Oaks, CA: Sage. https://doi.org/10.1207/s15327906mbr4104_3

Morgan, P. L., Farkas, G., Hillemeier, M. M., \& Maczuga, S. (2016). Science achievement gaps begin very early, persist, and are largely explained by modifiable factors. Educational Researcher, 45(1), 1835. https:/ / doi.org/10.3102/0013189X16633182

Mujtaba, T., \& Reiss, M. J. (2014). A survey of psychological, motivational, family and perceptions of physics education factors that explain 15-year-old students' aspirations to study physics in post-compulsory English schools. International Journal of Science and Mathematics Education, 12(2), 371-393. https:/ / doi.org/10.1007/ s10763-013-9404-1

Munce, R., \& Fraser, E. (2012). Where are the STEM students? What are their career interests? Where are the STEM jobs? Retrieved from https://www.daily herald.com/assets/PDF/DA127758822.pdf

National Science Board. (2018). Science and engineering indicators 2018 (NSB-2018-1). Alexandria, VA: National Science Foundation. Retrieved from https:/ / www.nsf.gov/statistics/indicators /

National Science Foundation (NSF). (2010). NSF STEM classification of instructional programs crosswalk. Retrieved from https://www.lsamp.org/help/ help_stem_cip_2010.cfm

National Science Foundation. (2017). Women, minorities, and persons with disabilities in science and engineering: 2017 digest (NSF 17-310). Arlington, VA: Author. Retrieved from www.nsf.gov/statistics/wmpd/

Noonan, R. (2017). STEM Jobs: 2017 Update (ESA Issue Brief \# 02-17). Washington, DC: Office of the Chief Economist, U.S. Department of Commerce. Retrieved from http://www.esa.gov/reports/ stem-jobs-2017-update

Riegle-Crumb, C., Farkas, G., \& Muller, C. (2006). The role of gender and friendship in advanced course taking. Sociology of Education, 79(3), 206-228. https:/ / doi.org/10.1177/003804070607900302

Rosenthal, R., \& Jacobson, L. (1968). Pygmalion in the classroom: Teacher expectations and pupils' intellectual development. New York, NY: Holt, Rinehart \& Winston.

Rozek, C. S., Svoboda, R. C., Harackiewicz, J. M., Hulleman, C. S., \& Hyde, J. S. (2017). Utility-value intervention with parents increases students' STEM preparation and career pursuit. Proceedings of the 
National Academy of Sciences, 114(5), 909-914. https:// doi.org/10.1073/pnas.1607386114

Sadler, P. M., Sonnert, G., Hazari, Z., \& Tai, R. (2012). Stability and volatility of STEM career interest in high school: A gender study. Science Education, 96(3), 411-427. https:/ / doi.org/10.1002/sce.21007

Sahin, A. (2013). STEM clubs and science fair competitions: Effects on post-secondary matriculation. Journal of STEM Education: Innovations and Research, 14(1), 7-13.

Sahin, A., \& Top, N. (2015). STEM students on the stage (sos): Promoting student voice and choice in STEM education through an interdisciplinary, standardsfocused project-based learning approach. Journal of STEM Education: Innovation and Research. 16(3), 2433.

Sahin, A., Ayar, M. C., \& Adiguzel, T. (2014). STEMrelated after-school program activities and associated outcomes on student learning. Educational Sciences: Theory \& Practice, 14(1), 13-26.

Sahin, A., Ekmekci, A., \& Waxman, H. C. (2017a). Collective effects of individual, behavioral, and contextual Factors on high school students' future STEM career plans. International Journal of Science and Mathematics Education, 1-21. https:/ / doi.org/10.1007/s10763-017-9847-x

Sahin, A., Gulacar, O., \& Stuessy, C. (2014). High school students' perceptions of the effects of science Olympiad on their STEM career aspirations and 21st century skill development. Research in Science Education, 45(6), 785-805.

Sass, T. R. (2015). Understanding the STEM pipeline (CALDER \#125). Washington, DC: American Institutes for Research.

Schunk, D. H., Meece, J. L., \& Pintrich, P. R. (2014). Motivation in education: Theory, research, and applications ( $4^{\text {th }}$ ed.). Columbus. OH: Pearson.

Sevdalis, C., \& Skoumios, M. (2014). Non-formal and informal science learning: Teachers' conceptions. International Journal of Science in Society, 5(4), 13-25. https:// doi.org/10.18848/18366236/CGP/v05i04/59287

Shells, T. (2015). Expectations of teachers, administrators, and parents for the academic achievement of students (Unpublished doctoral dissertation). Walden University, Minneapolis, $\mathrm{MN}$.

Shumow, L., \& Schmidt, J. A. (2013). Academic grades and motivation in high school science classrooms among male and female students: Associations with teachers' characteristics, beliefs and practices. Journal of Education Research, 7(1), 53-72.

Steenbergen-Hu, S., \& Olszewski-Kubilius, P. (2017). Factors that contributed to gifted students' success on STEM pathways: The role of race, personal interests, and aspects of high school experience. Journal for the Education of the Gifted, 40(2), 99-134. https:// doi.org/10.1177/0162353217701022

Tai, R. H., Liu, C. Q., Maltese, A. V., \& Fan, X. (2006). Planning early for careers in science. Science, 312, 1143-1144.

https:/ / doi.org/10.1126/science.1128690

Taskinen, P. H., Dietrich, J., \& Kracke, B. (2016). The role of parental values and child-specific expectations in the science motivation and achievement of adolescent girls and boys. International Journal of Gender, Science and Technology, 8(1), 103-123.

Thomas, J. A., \& Strunk, K. K. (2017). Expectancy-value and children's science achievement: Parents matter. Journal of Research in Science Teaching, 54(6), 693-712. https:/ / doi.org/10.1002/tea.21382

Uitto, A. (2014). Interest, attitudes and self-efficacy beliefs explaining upper secondary school students' orientation towards biology related careers. International Journal of Science and Mathematics Education, 12, 1425-1444. https:/ / doi.org/10.1007/s10763-014-9516-2

Wang, X. (2013). Why students choose STEM majors: Motivation, high school learning, and postsecondary context of support. American Educational Research Journal, 50(5), 1081-1121. https:// doi.org/10.3102/0002831213488622

Wang, M. T., \& Degol, J. L. (2017). Gender gap in science, technology, engineering, and mathematics (STEM): Current knowledge, implications for practice, policy, and future directions. Educational Psychology Review, 29(1), 119-140. https://doi.org/10.1007/ s10648-015-9355-x

Xue, Y., \& Larson, R. C. (2015, May). STEM crisis or STEM surplus? Yes and yes. Monthly Labor Review (U.S. Bureau of Labor Statistics). https://doi.org/10.21916/mlr.2015.14

Yu, S. L., Corkin, D. M., \& Martin, J. P. (2017). STEM motivation and persistence among underrepresented minority students: A social cognitive perspective. In J. T. DeCuir-Gunby \& P. A. Schutz (Eds.), Race and ethnicity in the study of motivation in education (pp. 67-81). New York: Taylor \& Francis. 


\section{APPENDIX A}

*1. I agree to participate in this study and allow the use of information referred to in the attached letter.

\section{Yes†No}

\section{(a) Student Demographics}

*2. Gender

Male

Female

*3. Ethnicity

African American

Asian

Hispanic

White

*4. Lunch Status

Free

Reduced

Paid

\section{(b) Family Context}

*5. Did either of your parents receive a college degree in the United States?

Yes†No

*6. What is your parent's highest level of education?

Less than high school

High school diploma or GED

Associate Degree (two-year)

Bachelor's degree (4-year)

Master's degree or higher

\section{(c) School and Out-of-school-Related Activities}

*7. Which clubs have you attended in high school (including 9th grade)?

American Mathematics Competition

Advanced Research Club

Arduino Club

Astronomy

Biology

Computer Science Club

Drone FPV Racing Club

E-Cyber mMission

Environmentalists

FTC Robotics

Harmony Scientific Research Society

Health

Junior Solar Sprint
Math Contest

NABT Bio Club

PBL Club

Project Construction

Rocketry Club

Scale Modeling

Science Olympiad

Sea Perch

Solar Car Club

Shell Eco

3D Printing Club

Cheerleading

Chess

College Readiness and Leadership Program (CRLP)

College Readiness and Leadership Program (CRLP)

Drama

Folk Dance

French

Odyssey of the Mind

Poetry

Spanish

Other (please specify)

*12. Did you participate in Digital Storytelling Competition (DISTCO) with your STEM SOS project video in years below?

2015-2016

2016-2017

2017-2018

None

*13. Please enter the number of SCHOOLWIDE science fair events you participated in during high school (including 9 th and 10 th grade):

1-5

6-10

$11-15$

$16-20$

More

*14. Please enter the number of REGIONAL science fair events you participated in during high school (including 9th and 10th grade):

$$
1-5
$$

6-10

11-15

16-20

More 
${ }^{*} 15$. Please enter the number of STATE LEVEL science fair events you participated in during high school (including 9th and 10th grade):

$1-5$

6-10

11-15

$16-20$

More

*16. Please enter the number of INTERNATIONAL science fair events (e.g., ISWEEEP and Intel) you participated in during high school (including 9th and 10th grade):

$1-5$

6-10

$11-15$

$16-20$

More

*17. How many science, technology, engineering, and mathematics (STEM)-related summer camps did you participate in during high school years (including 9th and 10th grade)?

Enter your response here

*18. How many science, technology, engineering, and mathematics (STEM)-related internships did you attend at a medical or higher education institution (university) in high school (including 9th and 10th grade)?

Enter your response here

*19. Do you have intention to declare a science, technology, engineering, and mathematics (STEM)related major in college?

Yes†No

*20. Which STEM-related Advanced Placement (AP) courses have you taken so far (including $9^{\text {th }}$ and $10^{\text {th }}$ grade)?

AP Biology

AP Chemistry

AP Environmental Science

AP Physics 1

AP Physics 2

AP Physics C

AP Calculus A B

AP Calculus BC

AP Computer Science A

AP Computer Science Principles

AP Statistics

Other (Specify)
*21. Please choose three factors you think affect(ed) your career interest most.

Teachers

Parents

Science Fairs

Afterschool clubs

Summer Camps

Internships

Early exposure to math and/or science

Courses taken in high school

Gender

Socioeconomic status

Other: please specify

22. How many advanced Placement (AP) courses have you taken so far?

Enter your response here

26. What type of career do you want to pursue in after college?

Agricultural sciences Chemistry

Computer Science Engineering

Environmental science

Geosciences

Life/biological sciences

Mathematics

Physics/Astronomy

Medicine/Medical

Business

Social Sciences

Communication/RTF

Liberal Arts

Other (please specify)

34. Your current GPA

Strongly Agree

Agree

Neutral

Disagree

Strongly Disagree

\section{(d) Parent and Teacher Expectations}

24. How encouraging were your parents about going to college?

Not encouraging at all

Somewhat encouraging

Encouraging

Strongly Encouraging 
25. How encouraging were your STEM teachers about going to college?

Not encouraging at all

Somewhat encouraging

Encouraging

Strongly Encouraging

\section{(e) Students' Self-expectations About Their Future} Education, and Mathematics and Science Efficacy

23. What was your educational degree expectation about yourself during high school?

High school or less

Vocational training

Some college (ex: 2-year)

4-year college

Masters' degree

Doctorate or professional degree

27. Math has been my worst subject

Strongly Agree

Agree

Neutral

Disagree

Strongly Disagree

28. would consider choosing a career that uses math Strongly Agree

Agree

Neutral

Disagree

Strongly Disagree

29. Math is hard for me

Strongly Agree

Agree

Neutral

Disagree

Strongly Disagree

30. I am the type of student to do well in math

Strongly Agree

Agree

Neutral

Disagree

Strongly Disagree
31 I can handle most subject well but I cannot do a good job with math

Strongly Agree

Agree

Neutral

Disagree

Strongly Disagree

32. I am sure I could do advanced work in math

Strongly Agree

Agree

Neutral

Disagree

Strongly Disagree

33. I am good at math

Strongly Agree

Agree

Neutral

Disagree

Strongly Disagree

35. I am sure of myself when I do science

Strongly Agree

Agree

Neutral

Disagree

Strongly Disagree

36. I would consider a career in science

Strongly Agree

Agree

Neutral

Disagree

Strongly Disagree

37. I expect to use science when I get out of school Strongly Agree

Agree

Neutral

Disagree

Strongly Disagree

38. Knowing science will help me earn a living Strongly Agree

Agree

Neutral

Disagree

Strongly Disagree 
39. I will need science for my future work

Strongly Agree

Agree

Neutral

Disagree

Strongly Disagree

40 I know I can do well in science

Strongly Agree

Agree

Neutral

Disagree

Strongly Disagree

41. Science will be important to me in my life work

Strongly Agree

Agree

Neutral

Disagree

Strongly Disagree
42. I can handle most subjects well but I cannot do good job with science

Strongly Agree

Agree

Neutral

Disagree

Strongly Disagree

43. I am sure I could do advanced work in science Strongly Agree

Agree

Neutral

Disagree

Strongly Disagree

\section{http://www.ejmste.com}

